\title{
Budget Financing of Infrastructure Projects as a Tool for Implementing the Investment Policy of the Regions of the Russian Federation
}

\author{
Liliya S. Nevyantseva* Adil B.D. Dukhkhani \\ Ural state University of Economics, Yekaterinburg, Russia \\ *Corresponding author. Email: Inevyantseva@yandex.ru
}

\begin{abstract}
The article discusses the current practice of using budget financing for investment and infrastructure projects in the Russian Federation. The use of budget investments at the level of Federal districts of the Russian Federation is analyzed. It is established that the maximum concentration of Federal investments is typical for depressed regions (the North Caucasus and southern Federal districts), as well as for Moscow due to its strong competitive advantages. The dynamics of targeted subsidies from the center sent to the regions is shown. The main branches of budget financing of investment projects in Russia are indicated. Further prospects for budget financing in Russian regions are presented, in particular, spending on infrastructure projects for the next five years and the plan of the Federal targeted investment program of the Russian Federation for 2020. It is noted that at the current stage of budget investment in the development of regional economies is not enough, in this regard, the factors that affect the incomplete use of budget funds in project financing are highlighted. Some approaches to the formation and implementation of investment policy at the regional level to improve the efficiency of budget funds are proposed.
\end{abstract}

Keywords: budget investments, budget financing, investment project, infrastructure, regions, investment policy

\section{INTRODUCTION}

The current stage of regional development in Russia is taking place in the context of a transition to a system of strategic state planning designed to eliminate a complex of spatial and socio-economic problems in the country. To achieve the goals of strategic planning, it is important to clearly organize the management of the national economy as a whole, and therefore it is necessary to adhere to a systematic and comprehensive approach to setting strategic development goals for the long term. In the current situation, the investment component of the regional policy is particularly relevant, in which a block of Federal and regional projects is being formed to ensure balanced development and economic growth. The implementation of an effective investment policy at the level of Russian regions in such conditions must fully comply with the priority areas and tasks set by the Federal center to ensure structural changes in regional economies in accordance with long-term strategies for their development.

Decree of the President of the Russian Federation no. 204 dated 07.05.2018 «On national goals and strategic objectives for the development of the Russian Federation for the period up to 2024» sets the task of joining Russia among the five largest economies in the world. As you know, to ensure GDP growth, it is necessary to increase investments in fixed assets from various sources, including budgets. Research by foreign authors has shown that not only private but also public investment has a positive impact on GDP. For example, in the United States, the multiplier effect of budget investments was 1.92 in the short term and 3.21 in the long term [1]. In India, the amount of state funding for national projects is $90 \%$. In General, in the modern world, public financing of investment and infrastructure projects is positioned as one of the strongest tools for ensuring a sustainable investment process at the macro-and meso-level, being the most important factor in the development of social production.

In Russian practice, the concept of state budget investments was first defined in the law of the RSFSR of October 10, 1991 N 1734-I "on the basics of the budget structure and budget process in the RSFSR". According to this law, budget expenditures at all levels were divided into current (operational) and capital (investment) expenditures. The totality of capital expenditures was the basis for the development budget of the relevant public authority, including allocations for financing investment and innovation activities and other costs associated with expanded reproduction. The current expenditure budget included all other expenditures that were not included in the development budget.

At the present stage, budget investments are regulated by the Budget code of the Russian Federation (starting from January 1, 2000 to the present). Article 6 of the tax code of the Russian Federation defines that budget investments are budget funds directed to creating or increasing the value of state (municipal) property at the expense of budget funds [2]. 
The budget legislation of the Russian Federation provides for two main forms of expenses related to direct investment activities of a Russian subject. Thus, according to article 69, 69.1 of the Budget code of the Russian Federation, budget allocations for the provision of state (municipal) services (performance of works) include allocations for the implementation of budget investments in objects of state (municipal) property [2]. In the context of the budget classification of the Russian Federation by types of budget expenditures, this may include actual budget investments and subsidies for capital investments to budget and Autonomous institutions, state (municipal) unitary enterprises [3]. As a General rule, funds from the budget are directed to investment objects established by law on the basis of existing targeted long-term development programs or other regulations.

Issues of budget financing of investments are widely covered in the works of modern scientists and economists. For example, R. A. Alandarov [1,4] analyses the role of Federal budget investments in the socio-economic development of the Russian Federation and assesses the quality of financial management of budget investments in the country; A. A. Derkach [5] studies the formation of the investment social budget to Finance capital investments in the social sector; O. V. Kiseleva [6] reveals the role of budget financing in the investment policy of the Russian Federation; Kuznetsova [7,8] devoted to Federal support for investment in Russia and problems of their evaluation; V. Arbatskaya [3] covers the legal aspects of investment budget expenditures; V. N. Adronova and D. O. Maslakova in his work [9] compare the regions of the Russian Federation in terms of investment financing, including budgetary funds; in T. V. Shchukina [10] and L. A. Michalinos [11] provides an analytical analysis of the development budget investments in the territory of the Russian Federation; O. Ivanov and E. M. Buchwald [12] covers in detail the investment priorities of the Russian Federation on a strategic level.

In the continuation of scientific papers on budget financing of investment projects and programs in the Russian Federation, the authors will consider the regional aspect of this direction. The relevance of this study is due to the increasing role of public investment in the polarized development of Russian regions. Within the framework of regional investment strategies, budget investments are positioned as an effective tool for the development of the territory, which allows launching new infrastructure and upgrading existing ones. As a rule, budget funds are used to Finance road construction projects, social and environmental purposes that are extremely important for the Russian state as a whole, but at the same time unattractive for private or foreign investors due to high risks and uncertain economic effect. Thus, investments from the Federal budget and the budgets of the Russian regions have a positive impact on the overall development of the national economy, allowing you to reduce the boundaries of the economic lag of depressed territories from developed ones. The purpose of this article is to identify contemporary trends in budget financing of investment projects at the level of regions of the Russian Federation (hereinafter - RF), identifying the main problems hindering the use of budget funds in the Russian economy, and making recommendations for improving the effectiveness of the investment policy of the Russian regions through rational use of investment.

The article is prepared using the main research methods: analysis, synthesis, comparison and generalization of results.

\section{BUDGET INVESTMENTS IN FEDERAL DISTRICTS OF THE RUSSIAN FEDERATION: CURRENT STATE}

Turning to the quantitative analysis of budget investments at the level of individual regional units (Federal districts), we will assess the situation in the sphere of budget financing at the national level.

For Figure 1 it can be seen that at present budget investments in the Russian economy tend to gradually decrease. Thus, in the period 2015-2018, the share of budget investments in the consolidated budgets of the regions of the Russian Federation decreased from $13.4 \%$ to $10.8 \%$. This is due to a reduction in the regional budget surplus (exception-2018) due to the deterioration of the global commodity markets, which negatively affected income tax revenues to the corresponding budgets of the Russian regions. 


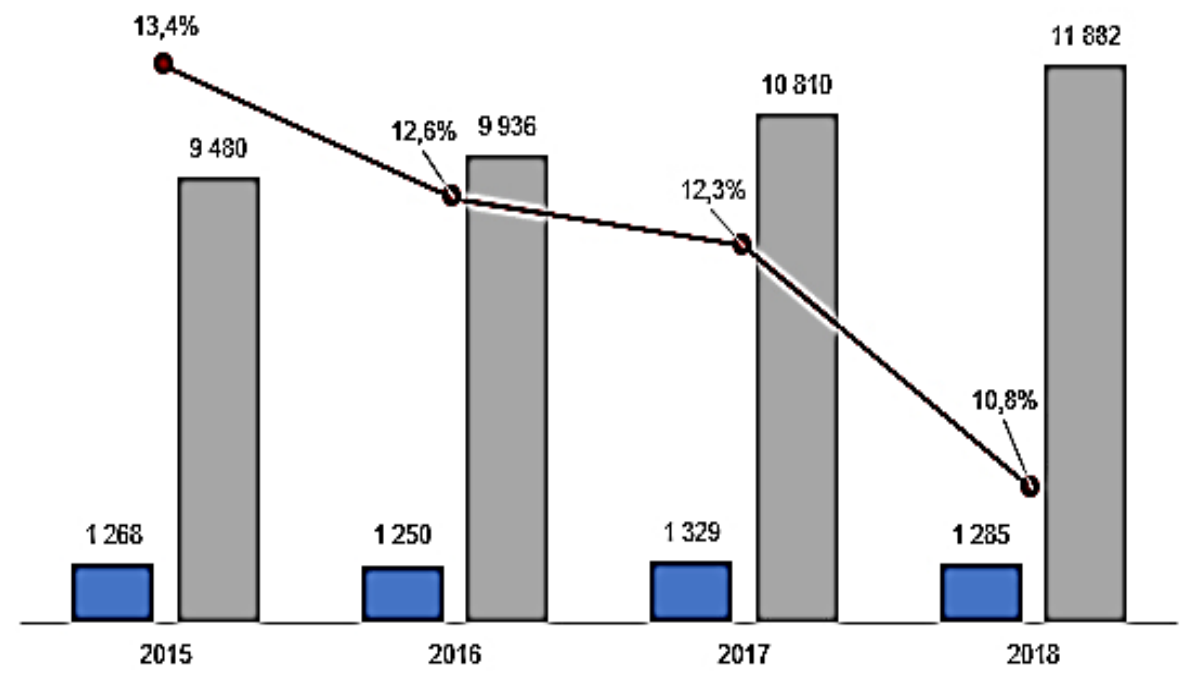

Budget investments in the consolidated regional budgets, billion rubles

Total expenditures of consolidated regional budgets, billion rubles

Budget investments in $\%$ of expenses of consolidated regional budgets

Figure 1 Dynamics of budget investments in the consolidated budgets of Russian regions [13]

Despite the fact that the consolidated budget revenues increased in 2018 for the first time in the last 11 years, the number of regions where fixed capital investment shows a negative trend has increased. So, against the background of improving the situation in the sphere of budgets, an investment decline was recorded in 32 regions of the Russian Federation, which is $40 \%$ of the total number of Russian regions. In General, investments in fixed assets in the country in 2018 increased by $4.3 \%$ compared to the previous year and reached 17 trillion 595 billion rubles. Note that the negative dynamics of direct investment is typical for underdeveloped and lowincome territories that are experiencing an acute deficit in project financing.

In table. 1 we will present directly statistics on budget sources of investment financing in the Russian Federation for 2018.

Table 1 Distribution of fixed capital investments by budget sources of financing, 2018 [14]

\begin{tabular}{|l|c|c|c|c|}
\hline \multicolumn{1}{|c|}{ Distrito Federal } & $\begin{array}{c}\text { Investments in fixed } \\
\text { capital, mln rubles }\end{array}$ & $\begin{array}{c}\text { Budget funds } \\
\text { only, \% }\end{array}$ & $\begin{array}{c}\text { of Federal } \\
\text { budget, \% }\end{array}$ & $\begin{array}{c}\text { of the Budgets of } \\
\text { subjects of the } \\
\text { RF, \% }\end{array}$ \\
\hline Russian Federation & 17595028 & 15,3 & 7,6 & 6,6 \\
\hline Central & 4372564 & 20,8 & 6,7 & 12,9 \\
\hline Northwest & 2088934 & 15,8 & 9,1 & 5,9 \\
\hline South & 1406247 & 32,2 & 26,4 & 4,2 \\
\hline The North Caucasus & 550920 & 35,3 & 25,3 & 7,9 \\
\hline Privolzhsky & 2467769 & 12,3 & 5,7 & 5,6 \\
\hline Ural & 2931256 & 4,5 & 1,2 & 2,5 \\
\hline Siberian & 1574244 & 11,3 & 5,5 & 4,3 \\
\hline Far-East & 1394467 & 11,9 & 7,1 & 3,6 \\
\hline
\end{tabular}

As we can see, budget money in Russia is directed mainly to the southern and North Caucasus Federal districts, and project funding from Federal funds prevails. The Central government actively invests in regions that are not attractive to private investors, and state funding in such subjects is usually charitable in nature (for example, the republics of Dagestan, Ingushetia, Chechnya, North Ossetia, etc.). The southern Federal district also received $1 / 3$ of the Federal funds, where the sports infrastructure for the world Cup was actively built and the construction of a bridge across the Kerch Strait in the Krasnodar region was intensively 
financed. Up to $1 / 4$ of the Federal investment is directed to the Central Federal district (mainly to Moscow). This is due to both the agglomeration effect and the presence of competitive advantages due to the presence of an extensive infrastructure and transport system, science cities, production capacity, etc. Almost complete absence of budget investments is typical for the Ural Federal district, where an important source of project financing, along with the enterprises ' own funds, is the credit resources of banks (about 23\%). This is due to a small amount of funding for districts of the Tyumen region that specialize in oil and gas production.

According to Russian law, when building regional or municipal infrastructure at the expense of the Federal budget, the corresponding funds are transferred to the budgets of the subjects of the Russian Federation or local budgets in the form of targeted subsidies and transfers. In table. 2 shows the dynamics of Federal budget subsidies sent to Russian regions in 2015-2018.

Table 2 Infrastructure subsidies from the Federal budget to regions [15]

\begin{tabular}{|l|c|c|c|c|c|}
\hline \multicolumn{1}{|c|}{ Indicator } & $\mathbf{2 0 1 5}$ & $\mathbf{2 0 1 6}$ & $\mathbf{2 0 1 7}$ & $\mathbf{2 0 1 8}$ & $\mathbf{2 0 1 9}$ \\
\hline Subsidies for financing capital investments, billion rubles. & 118,7 & 88,8 & 114,4 & 118,2 & 123,5 \\
\hline Ratio of subsidies to Federal spending, \% & 22 & 17 & 21 & 26 & 29 \\
\hline Subsidies in regional spending, \% & 10 & 7 & 8 & 9 & 8 \\
\hline
\end{tabular}

We see that the volume of subsidies from the center shows a positive trend in recent years. Their share of the amount of Federal spending on infrastructure projects is also increasing, but this is due to the fact that Federal spending on the relevant goals is being reduced directly. At the same time, Federal subsidies, according to experts
[15], do not even reach $0.2 \%$ of Russia's GDP, and as part of regional infrastructure spending in recent years have remained virtually unchanged.

The main branches of budget financing of investment projects in 2018 are presented in table 3.

Table 3 Dynamics and structure of budget investments in consolidated budgets [13]

\begin{tabular}{|l|c|c|c|c|}
\hline \multirow{2}{*}{ Direction } & \multicolumn{2}{c|}{ Billion rubles } & \multicolumn{2}{c|}{$\begin{array}{c}\text { Share in the total investment } \\
\text { structure, \% }\end{array}$} \\
\cline { 2 - 5 } & $\mathbf{2 0 1 7}$ & $\mathbf{2 0 1 8}$ & $\mathbf{2 0 1 7}$ & $\mathbf{2 0 1 8}$ \\
\hline Road facilities & 368,2 & 393,3 & 27,7 & 30,6 \\
\hline Housing and communal services & 258,5 & 220,3 & 19,5 & 17,1 \\
\hline Transport & 260,1 & 213,5 & 19,6 & 16,6 \\
\hline Education & 138,8 & 182,1 & 10,4 & 14,2 \\
\hline
\end{tabular}

Thus, public investment in Russia is primarily institutional in nature and is aimed at providing various public goods: construction of road and transport networks, modernization of housing and communal services, and ensuring the competitiveness of human capital. It can be noted that the directions of the financed industries correspond to the Comprehensive plan for the modernization and expansion of the main infrastructure for the period up to 2024 , as well as numerous national projects in General.

As E. M. Primakov emphasized, a breakthrough in economic growth can take place only when a number of megaprojects are implemented. R. S. Grinberg also noted that for us, megaprojects are an alternative option for survival in this world, first of all, the construction of high-speed Railways and highways that "pull together" the space of Russia. However, the policy of megaprojects should be carried out very carefully, based on the principle of territorial balance, otherwise the results of these projects may lead to even greater economic differentiation of the country's regions both in terms of GRP and investment activity. In addition, various megaprojects should be formed at the Federal level, through the spatial development Strategy of the Russian Federation. This will allow the subjects of the Russian Federation to adequately reflect the possible effect of the implementation of megaprojects in their strategies for socio-economic and investment development [12]. In this regard, in table. 4 let's present a plan for budget investments in the infrastructure of the Russian regions. 
Table 4 Expenditures on infrastructure projects planned for 2019-2024 and the impact of these projects on the regions [16]

\begin{tabular}{|l|c|c|c|}
\hline \multicolumn{1}{|c|}{ Distrito Federal } & $\begin{array}{c}\text { Cost } \\
\text { projects', } \\
\text { billion rubles }\end{array}$ & $\begin{array}{c}\text { Average infrastructure } \\
\text { expenditures per capita, } \\
\text { thousand rubles }\end{array}$ & Effect for regions \\
\hline Russian Federation & 14519 & 16,5 & Strong \\
\hline Central & 2459 & 10,4 & Moderate \\
\hline Central Federal district without Moscow & 2459 & 15,3 & Strong \\
\hline Northwest & 1290 & 15,4 & Moderate \\
\hline South & 1315 & 13,3 & Strong \\
\hline The North Caucasus & 351 & 5,9 & Moderate \\
\hline Privolzhsky & 2151 & 12,2 & Moderate \\
\hline Ural & 1149 & 15,5 & Moderate \\
\hline Siberian & 1884 & 18,3 & Strong \\
\hline Far-East & 3920 & 79,8 & Very strong \\
\hline
\end{tabular}

As you can see, in just five years, it is planned to implement many investment and infrastructure projects with a total cost of 14,519 billion rubles. Experts analyzed the impact of these projects on the regional economy. Thus, the strongest effect of the planned investments is expected in the far East, where almost 4 trillion rubles will be invested from 2019 to 2024 . significant regional growth is also expected in the Central, southern and Siberian Federal districts. Despite the considerable amount of budget funding, the effect on the economies of the North-Western and Volga Federal districts will be more moderate, but also important.

At the same time, the bulk of investment is expected to be directed to three segments: the transport, oil and gas transportation and electric power industries. Regarding the transport direction, it is expected to improve the communication routes between major cities - regional centers of economic growth. A significant part of the projects will be concentrated around the largest administrative centers-Moscow, St. Petersburg, Nizhny Novgorod and Kazan. In the electric power segment, significant investments are envisaged in upgrading existing capacities throughout the country: $5 \%$ of the total capacity being upgraded will be located in the far East, $19 \%$ in Siberia, and $76 \%$ in the European part of Russia and the Urals. In the oil and gas transportation segment, a significant share of investments will be spent on the Power of Siberia and Eastern Siberia - Pacific ocean gas pipelines, and, consequently, capital investment will be concentrated in Siberia and the far East [16].

However, we have to state that at the current stage, investments in the development of priority industries are clearly insufficient, and most of the funds are spent on maintaining existing facilities. Thus, according to the Treasury's operational data on budget execution, as of
December 30, 2019, Federal funds for the comprehensive plan were spent only by $83.7 \%$, and for national projects-by $90.8 \%$. Money entered the economy unevenly, with a standard increase in spending by the end of the year. Authorities, especially regional ones, continue to use a tool that is closer to them - public procurement [15].

The authors agree with the views of economists $[11,17,18,19]$ that the following factors mainly influence the late and incomplete execution of national projects financed by budgetary funds:

- Systemic management problems resulting from the lack of a full-fledged strategic planning system that would take into account intersectoral and inter-regional relations;

- Poor quality of planning in the formation of a system of indicators for programs and projects;

- Inconsistency in the actions of ministries and departments in allocating and disbursing investment funds, and extremely poor coordination between the Central and regional governments. In particular, for 2020 and 2021, a significant number of regional subsidies have not been distributed, since the final agreement with the regions has not been established;

- Problems of administrative barriers and corruption related to the low level of competence of employees to prepare the necessary documentation, lack of control over the expenditure of budget funds, as well as the overall improper performance of all participants in the investment project of their obligations.

In order to solve these problems, as well as to activate investment processes at the national and regional levels and increase the efficiency of using budget investments, we believe that the following 
approaches and rules should be followed for implementing investment policy at the regional level:

- Be guided by the program-target approach to the implementation of the state investment policy as a whole;

- Refuse investment support for projects that, due to their targeted orientation, do not correspond to the priorities of the country's economic policy and individual regions;

- Improve the competence and efficiency of regional and municipal administrations in planning and using budget funds;

- Implement budget financing of investment activities of regions and municipalities strictly on the basis of developed regional structural and investment strategies;

- To improve normative-legal base in the sphere of regulation of budget funds, etc.

Experts predict [13] that in 2020 there will be a significant increase in budget investments financed through regional budgets. This will largely be due to the implementation of the new may decrees. According to the rules of the Budget code of the Russian Federation, financing of budget investments in capital construction projects at the expense of the Federal budget in the Russian Federation is carried out according to the Federal targeted investment program. In table. 5 let's present a plan for such a program for 2020 .

Table 5 Federal targeted investment program of the Russian Federation for 2020 [20]

\begin{tabular}{|l|c|c|}
\hline \multicolumn{1}{|c|}{ Distrito Federal } & Quantity objects (events) & Budget, thousand rubles \\
\hline Russian Federation & 1229 & 847600632,6 \\
\hline Central & 231 & 121713707,0 \\
\hline Northwest & 152 & 111103510,0 \\
\hline South & 222 & 151433742,1 \\
\hline The North Caucasus & 98 & 24048188,5 \\
\hline Privolzhsky & 151 & 56402420,0 \\
\hline Ural & 27 & 6920498,5 \\
\hline Siberian & 89 & 30225288,7 \\
\hline Far-East & 160 & 56810113,1 \\
\hline
\end{tabular}

Thus, a total of 1,229 projects are planned for 2020 for a total budget allocation of 847 million rubles. in the southern Federal district, the bulk of budget money will be sent to the Krasnodar territory (23 million rubles) and Sevastopol (21 million rubles). In Central - to Moscow (59 million rubles) and the Moscow region (38 million rubles). In the North-West - to Saint Petersburg (35 million rubles), Murmansk region (33 million rubles) and Leningrad region (19 million rubles). The least budget investments are directed to the economy of the Ural Federal district - only about 7 million rubles, of which 4.7 million rubles. it is supposed to be sent to the Chelyabinsk region.

It should be borne in mind that in the regions and municipalities, investments will mainly be funded by targeted transfers and subsidies from the Federal center, provided for by the relevant long-term target programs, and the level of co-financing from the regional budgets themselves will remain small.

In conclusion, we emphasize the importance of budget investments for the Russian economy at the present stage. For some regions of the Russian Federation, the use of budget financing in investment activities can help to create new progressive industries that can create the right structural changes in the regional economy. In the current conditions of regional development, it is important that budget investments contribute to the formation of a modern transport and road system, the modernization of housing and communal services, improving the competitiveness of human capital, and the reconstruction of education and health facilities. In General, in the conditions of uneven development of the Russian regions, the correct distribution of budget investments should contribute to the uniform formation of national welfare in the territorial and sectoral context.

\section{CONCLUSIONS}

Currently, Russia's budget policy is becoming more focused on stimulating investment activity. Theoretically, the following arguments can be made in favor of expanding the budget financing of the investment process in the Russian economy:

- the state budget serves as the accumulator of financial resources; 
[5] A. A. Derkach, Formation of the investment social budget in accordance with the state investment policy, in: Economics, statistics and Informatics. Vestnik UMO, 2014, no. 3, pp. 45-48.

[6] O. V. Kiseleva, the Role of budget financing in the investment policy of the Russian Federation, in: Finance and credit, 2011, no. 36 (468), pp. 55-59.

[7] O. V. Kuznetsova, Problems of evaluating Federal investment policy as a factor of regional development, in: Regional studies, 2014, no. 4, pp. 125-133.

[8] O. V. Kuznetsova, on Federal support for investment localization in Russia, in: Society and economy, 2016, no. 11 , pp. 105-123.

[9] V. N. Edronova, D. O. Maslakova, Complex comparative analysis of the subjects of the Russian Federation on investment financing, in: Finance and credit, 2018, no. 10, pp. 2359-2378. DOI: $10.24891 /$ fc. 24.10 .2359

[10] T. V. Shchukina, Trends and problems of development of budget investments, in: Vestnik universiteta, 2018, no. 9, pp. 127-133. DOI: 10.26425/1816-4277-2018-9-127-133

[11] L. A. Mikheikina, Analysis of budget financing of investments in the Russian Federation, in: collection: Russia: trends and prospects of development, Yearbook, 2017, pp. 616-619.

[12] O. B. Ivanov, E. M. Buchwald, Investment priorities in strategies for socio-economic development of Russian regions, in: STAGE: Economic theory, analysis, practice, 2018 , no. 2 , pp. 31-47. DOI: $10.24411 / 2071-$ 6435-2018-10014

[13] A. shurakov, Budgets of Russian regions in 2018: record surpluses, subsidies and restrained investments Available at: https://raexpert.ru/docbank/7bb/111/829/786e587521dd 44e155eebdf.pdf (accessed 07.03.2020).

[14] Regions Of Russia. Socio-economic indicators Available at: https://gks.ru/folder/210/document/13204 (accessed 07.03.2020).

[15] Investment in infrastructure. Analytical review Available at: https://infraone.ru/sites/default/files/analitika/2020/inve stitsii_v_infrastrukturu_2020_infraone_research.pdf (accessed 07.03.2020).
[4] R. A. Alandarov, Assessing the quality of financial management of budget investments in Russia, in: Economics. Taxes. Law, 2018, no. 6, pp. 69-79, DOI: 10.26794/1999-849X-2018-11-6-69-79 
http://www.ng.ru/economics/2019-11-

[16] Russian regions: where is the growth potential? Available

at: http://bratsk.org/uploads/media/8b5d908b731f1b23b7b 459b72ec0778563013c6f.pdf (accessed 07.03.2020).

[17] A. S. Bednyakov, L. A. Mierin, National projects of Russia: problems and solutions, in: Izvestia of the Saint Petersburg state University of Economics, 2019, no. 4 (118), pp. 20-25.

[18] A. Komrakov, National projects have mastered only half of the money Available at: 07/1_7721_projects.html (accessed 07.03.2020).

[19] V. Inozemtsev, National projects of the Russian Federation: implementation, problems and obstacles Available at: https://wik-end.com/news/v-strane-imire/v-strane-i-mire_9864.html (accessed 07.03.2020).

[20] Federal targeted investment program Available at: https://www.economy.gov.ru/material/departments/d17/ federalnaya_adresnaya_investicionnaya_programma/ (accessed 07.03.202 